Article

\title{
The Quest for Rural Sustainability in Russia
}

\author{
Stephen K. Wegren
}

Southern Methodist University; Dallas, TX 75205, USA; swegren@smu.edu; Tel.: +1-214-768-2523

Academic Editor: David J. O’Brien

Received: 5 April 2016; Accepted: 18 June 2016; Published: 28 June 2016

\begin{abstract}
Rural depopulation and the disappearance of villages in rural Russia occurred as part of the historical process of urbanization and industrialization. Rural depopulation also occurred for structural reasons having to do with village location, and for behavioral reasons whereby villagers react to primitive living conditions and poor economic prospects. Three possible strategies for addressing the problem of sustainable villages are considered. The government is attempting to improve rural living conditions, but rural depopulation is likely to continue. Characteristics of sustainable villages are outlined. Agro-tourism is analyzed for its potential to support sustainable villages.
\end{abstract}

Keywords: Rural Russia; rural depopulation; sustainable villages; agro-tourism; food sovereignty; green agriculture

\section{Introduction}

The term "sustainable" has different applications. One usage refers to ecological and environmental sustainability. In the developed first world concern for ecological sustainability can be traced to the late 1960s and into the early 1970s. By 1980, "sustainable" had come to mean a form of economic development that took account of finite resources and the needs of future generations [1]. The Brundtland Commission in 1987 defined sustainable development as "development that meets the needs of the present without compromising the ability of future generations to meet their own needs" [2]. This definition became the standard for the next 25 years. The irony is that some developing states have sustainable green agriculture because they are so poor they cannot afford industrial agricultural practices that center around expensive mineral, chemical, and mechanical inputs [3]. In developing states food security among the rural and urban poor is a bigger problem than agricultural production that is not ecologically sustainable [4].

Subsequent to the Brundtland definition, the U.S. Congress adopted a different meaning for sustainability in the Food, Agriculture, Conservation and Trade Act of 1990. Its definition recognized ecological health and community well-being as important elements of sustainable agriculture, but avoided the linkage to intergenerational impacts [5]. After 2002, however, the definition of sustainable development became more holistic, linking economic development, social inclusion, and environmental sustainability [1] (p. 5). In recent years, environmental sustainability has taken on added importance due to increasingly severe effects of climate change [1] (pp. 393-445). In addition, the depletion of water tables, global stagnation in grain yields, and climate-related drought in many countries threaten agricultural production [6].

A second application of sustainability refers to rural communities, which essentially concerns labor resources and rural demographics. Questions surrounding sustainable communities in developed nations are different from those in low-income states. In developed states, many agricultural processes are mechanized so farm labor is less important to food production. Even so, sustainable rural communities provide a range of services to farms and are important for keeping surrounding areas economically alive. In developing nations, questions about sustainable rural communities relate 
to the supply of labor and therefore impact food production directly. In developing countries, sustainable rural communities are defined by demographic measures such as birth rates, mortality rates, and family size.

Further, in developing nations, the vitality of sustainable rural communities is affected by state policy. Starting with the work of Michael Lipton in the 1970s urban bias became a powerful paradigm for urban-rural relations in the Third World and one-party states [7]. Urban bias defines urban-rural relationships and the ways in which regimes extract resources from the agricultural sector to the benefit of the non-rural sector [8-13]. The urban bias argument maintains that states act to protect urban interests and discriminate against rural interests. Urban bias argues that financial, productive, and human resources are deliberately pumped out of the countryside in order to benefit urban dwellers. Food producers are discriminated against on price and resource flows (although there may be variation according to type of production). Urban bias, therefore, leads to extractive and discriminatory policies against the rural sector. Severe urban bias creates incentives for rural dwellers to migrate from the countryside, thereby reducing the supply of labor and endangering the sustainability of rural communities.

The purpose of this article is to analyze why sustainable rural communities have been elusive in rural Russia, historically and in the contemporary period. The core arguments may be summarized thusly. Rural Russia has confronted two processes that complicate sustainable villages. First, Stalinist urban bias created incentives to migrate out of the countryside, far beyond what would be considered "normal" outmigration during industrialization. Second, Soviet agriculture adopted an industrial model of agricultural production, similar to that in capitalist nations but without the capitalism. As such, the model historically depended upon villages to supply labor. But Soviet policy did a poor job of creating livable conditions in the countryside, and thus rural outmigration undermined the goal of sustainable villages. To the present, state programs to improve rural living conditions have been ineffective in stemming rural depopulation. Alternative production models embodied in green agriculture are attainable for only very few producers who are favorably located. A diversified income strategy such as agro-tourism is underdeveloped. The upshot is that the quest for sustainable villages remains difficult.

\section{Russia's Historical Problem of Village Sustainability}

Historically, Russia has faced challenges surrounding village sustainability. For a good part of its history in the 20th century village sustainability in Russia was dealt with using non-market mechanisms. As a one-party authoritarian state, during the Soviet period rural interests were protected only when they aligned with those of the Communist Party. Moreover, the state planned not only food production but also rural communities and their economic relations.

The collectivization of agriculture under Stalin represented the adoption of an agricultural model that resembled the one found in capitalist nations [14]. This model was dependent upon the industrialization of production, the application of chemicals and pesticides, widespread irrigation, and mechanized production processes. The Soviet state owned and controlled the vertical and horizontal chains of production and distribution, similar to the second food regime in capitalist countries [15] (pp. 21-40). The industrial agricultural model of agriculture required cheap labor to produce food for the cities. The Stalinist model combined the industrialization of agriculture and state policy, exploiting rural labor resources and extracting commodities from the countryside.

Thus, Russia is an example of a state-driven, top-down model that contrasts with the bottom-up and individual-driven sustainability model in democracies. Today, the state remains strong and although it no longer plans communities, much of the impetus for achieving sustainability comes from government. Russia's sustainability question has always centered around villages that provide labor to the industrial-agricultural complex. When contemporary Russian policymakers talk about sustainable rural communities, they have in mind ensuring sufficient labor supply for large farms, not sustainable 
villages based on food sovereignty [15] (57-60). The remainder of this paper investigates the quest for village sustainability, starting with the Soviet period.

\subsection{The Soviet Period}

Rural depopulation in Russia, and with it the disappearance of rural communities, has been going on for more than a century. During the first half of the 20th century, urbanization and industrialization led to significant rural outmigration. The urban population comprised just $15 \%$ of the total population in 1897, and just $18 \%$ as late as 1926 [16]. Urbanization really took off after 1926 and with the push for rapid industrialization the percentage of the urban population doubled by 1941. After a migratory respite during WWII, urbanization restarted and by the late 1950s the urban population officially became the majority. In short, Russia had a shared experience of rural outmigration with other industrializing nations.

Russian rural outmigration also had unique features. In the late 1920s and early 1930s, Stalin's collectivization represented the introduction of an industrial model of agricultural production, similar to what scholars today call the second food regime. In the Soviet case, state and collective farms drew heavily from village labor. The introduction of tractors and other mechanized processes was just beginning. Although the initial streams of rural outmigration were inherent to industrialization, motives to leave the countryside were strengthened by a severe anti-rural bias.

During the Stalin years, the rural population fell victim to state strategy that pursued urban bias. State policy viewed agriculture as a sector from which resources could be pumped out to support broader economic development. Farms were discriminated against on price and starved for investment. Rural dwellers were discriminated against on living conditions, wages, services, and economic opportunity. The consequence of state urban bias was a rural population that lived in squalor. Even foreign experts who had been hired to assist with the creation of industrial farms were affected. A Central Committee report notes that, "Foreign workers were also not used to the everyday hardships that were commonplace they missed conveniences such as pillowcases, drinking water, and washstands. Without satisfying food, without newspapers, without regular mail from their home country these workers develop a counterrevolutionary attitude and try hard to return to their home countries" [17].

The coming to power of Nikita Khrushchev (1956-1964) legitimized the idea in party leadership circles that "surplus" resources could not be extracted from agriculture indefinitely. He wanted to revitalize agriculture, which went hand in hand with his vision of the USSR as a rising power that could challenge the United States. His various attempts at reforming the agricultural sector-the Virgin Lands program, the dissolution of the Machine Tractor Stations, the corn campaign, amalgamation of collective farms-were intended to increase food production. These initiatives varied in their success $[18,19]$.

A strong agricultural sector required sustainable rural communities, but rural depopulation continued even after the nation became majoritarian urban. Khrushchev was the first Soviet leader to address rural outmigration, introducing the idea to create agrogorods (literally translated as agro-cities) in the 1950s so as to bring the urban way of life to rural areas. When that idea failed, Khrushchev undertook village consolidation, dividing villages into two categories: perspektivnye, or those that were viable and had a future, and neperspektionye, villages that were not viable and were destined to disappear [20] (p. 658). Villages in the neperspektivnye category were further divided into two groups: the first was to be merged with larger, more viable villages in the near future, and a second group that was to be allowed to die out [21]. This second category contained villages comprised mainly of pensioners. Regions with a large number of smaller villages, for instance in European non-Black Earth regions of Russia and in the Baltic states, had higher percentages of villages classified as non-viable. Once a village was classified as neperspektivnye, a ban on new construction was enacted and that in turn spurred a spatial concentration of rural services [22]. Generally, planners aimed for rural settlements of 1000-2000 people, the threshold for economies of scale for services and housing [20] (p. 659). 
Thus, village consolidation was the regime's answer to the problem of sustainable rural communities and was intended to create fewer, but larger rural communities. Village consolidation remained in force until the late 1970s when it was finally ended [23].

It is also important to keep in mind that Soviet labor was not free to move at will. There was an elaborate approval process for a farm worker wanting to relocate that made it cumbersome, but not impossible, to change jobs and location. Most relocations were the result of the person leaving the countryside for urban employment. Control over the movement of labor was used by Soviet planners for purposes of directed development, allocation of labor resources, and to prevent overtaxing the supply of urban housing in large cities. Labor input into farms was planned, just as the other inputs such as machinery and equipment, animals, seed, and housing were. Young people who graduated from an agricultural institute or university were assigned employment on a state or collective farm. Semi-controlled population movement was also important because most rural dwellers were employed on state and collective farms [24] (pp. 169-170). The number of rural persons employed in non-farm labor increased over time but remained a distinct minority. Wadekin calculated that non-farm rural personnel constituted about $27 \%$ of the rural population in the late 1950 s, which increased to about $32 \%-33 \%$ in the 1960 s [24] (p. 163).

The regime of Leonid Brezhnev (1964-1982) responded to the rural depopulation problem in two ways. First, a second wave of industrialization of agriculture occurred, as money was poured into the construction of mechanized animal complexes, poultry processing plants, and increased specialization on farms. The second wave of agricultural industrialization indirectly addressed outmigration by increasing wage tariffs for farm employees with specialized skills. This second wave was not intended to substitute mechanization for people but instead was geared to make agricultural labor a bit less onerous.

A second approach to address rural depopulation was the policy of narrowing socioeconomic differences between the city and the countryside. This policy, called sblizhenie, was formally introduced in 1965. Positive outcomes began to appear in the 1970s as rural standards of living improved in several ways $[25,26]$. One improvement was the relaxation (or removal) of many restrictions that had been placed on household subsidiary agriculture (lichnoe podsobnoe khoziaistvo) during the latter Khrushchev period. Household subsidiary plots were used by nearly every rural family and constituted an important supplementary source of non-monetary and monetary income family and constituted an important supplementary source of non-monetary and monetary income [27]. The removal of restrictions led to larger average sizes of plots, more total land used for subsidiary farming, more animals per household, and higher levels of output from this non-state sector. Households benefited from more income in kind and as a source of food. Sblizhenie also addressed income differences between farm and industrial workers. Wages of collective farm workers were increased, especially for higher-skilled positions. Farm wages were also monetized, although weak farms had difficulty moving to a monetary system and continued to pay wages in kind [28] (100-101). Collective farm workers were also made eligible for the state pension system. The combination of increased economic security represented an effort by the regime to make farm work less unattractive.

There was also improvement in the availability of consumer goods and provision of rural services. Rural dwellers experienced improvement in three areas. (1) Rural housing improved. During the Brezhnev years, significant improvements were made in providing rural housing with running water, hot water, indoor plumbing, central heating, electricity, and telephones; (2) Everyday services (bytovye uslugi) improved, which included laundry, dry cleaning, barbers, photographers, repair services, tailors, and home repair; (3) Access to communal services improved, such as education and health care. These services were almost entirely financed and provided by farm enterprises.

Improvements were documented in rural housing and connection to gas; in the purchase of durable consumer goods; in the level of retail trade; and in the provision of services such as telephones, access to education, access to physicians, and rural roads with hard pavement [29]. Although there was improvement, the urban-rural gap remained substantial and the rural quality was poor relative to urban 
locales and by international standards. Rural households in even agriculturally productive regions such as Rostov Oblast in the south had insufficient services and infrastructure [28] (pp. 104-105). One author attributes the shortcomings even in the south to "many years of ignoring a series of objective laws of economic development and the domination of command-administrative methods of management" [28] (p. 105). Thus, the countryside remained starved for services of all kinds, despite improvements under Brezhnev, which is to say that the "pull" factor of urban life remained [30].

In order to improve the rural standard of living and stem rural outmigration from the Russian non-Black Earth areas, the Communist Party Central Committee adopted a resolution in 1974 to improve rural social conditions [31]. During 1976-1980, about $18 \%$ of state investments in the non-Black Earth was devoted to the construction of housing and schools, roads, and other infrastructure [28] (p. 89). Subsequent policy decisions in 1978 and 1982 allocated higher percentages to rural social purposes in recognition of enormous differentials between rural and urban life, much greater than in developed Western nations [32].

Rural dwellers were motivated to search for a better standard of living. For this reason, rural depopulation from remote rural regions was much more severe than from areas classified as rural but with good proximity to a raion or oblast center. A primitive standard of living and an absence of services in remote rural villages led to a decline in the rural population. Whereas in 1959 the rural population comprised $48 \%$ of the total population (55.9 million people), in 1979 it fell to $31 \%$ (42.2 million people) [33]. Because the natural increase (the ratio of births to deaths) in rural Russia remained positive until 1991, rural depopulation was due to outmigration. Thus, from the 1950s to the late 1970s, the village sustainability problem changed from being a function of urbanization to one that stemmed from poor living conditions in rural areas.

The dramatic decline in rural population-nearly one million persons annually for two decades-had clear regional characteristics [34]. Much of the migratory outflow came from the non-Black Earth regions in central Russia. A paradoxical situation arose whereby farms in Central European Russia experienced labor shortages even though at the same time a large percentage of the population was employed in agriculture. The Brezhnev regime was particularly concerned about an emerging shortage of rural service personnel. It was not just the outmigration of rural labor that was concerning, it was the fact that the highly skilled and rural youth departed in the greatest numbers. The Brezhnev regime attempted to improve rural life as a strategy to slow rural depopulation, but ultimately it is difficult to conclude that the effort was successful.

Although Mikhail Gorbachev came to power in 1985, it was not until 1989 that the Communist Party adopted a program to address rural depopulation and sustainable villages. In April 1989, the party and the USSR Council of Ministers adopted a resolution, "On the Program for the Social Development of the Countryside" [35]. The program attached "the greatest possible importance to the further strengthening of the material and technical base of the social and cultural sphere in the countryside ... with measures to improve the quality of rural working people's lives" [35]. The "most important task" was to give every rural family a separate apartment or individual home by 1998 . The program called for access to gas to increase by a factor of 2.5 , and gas was to heat at least five million rural dwellings by 1995 . Hard surface roads were to be built linking farms and raion centers by 1991. Schools, vocational and educational organizations were to be built and "fully staffed with skilled pedagogical cadres." These organizations were to be supplied with "modern technical facilities, teaching aids, furniture, and equipment" [35]. The reality was that the program came too late in the life cycle of the USSR. In 1990, the economy began to contract and by 1991 inflation was spiking, government revenues were eroding, and the growing budget deficit precluded this program from being implemented. In late 1990, the Russian Republic (an administrative entity within the USSR) adopted a law on the social development of the countryside, stipulating that $15 \%$ of national income should be allocated to rural development; in reality, the law went unfunded and acted mainly as a symbol of intent rather than reality [36]. 
That said, under Gorbachev agrarian policy went through different stages while initially adhering to the goals of sblizhenie. The first phase of agrarian reform was to "accelerate" farm production, an emphasis found in the economy at large through the policy of uskorenie, which essentially meant to improve performance without systemic or structural change. A second phase sought to create economic incentives to remain in the countryside. Gorbachev increased wage tariffs for highly specialized labor categories. He ended limits on livestock raised on private plots so households could eat better and maybe sell more. He also loosened restrictions on income from non-state employment.

A third phase witnessed the introduction of a land leasing policy that allowed private citizens to lease land from state and collective farms. The goal was to create limited economic freedom and opportunity to earn higher income. By 1988-1989, Gorbachev's social policy had shifted, moving away from traditional social justice [37]. This was true for the rural sector as well. Gorbachev ended the public policy goal that urban and rural standards of living could be fully equalized. Instead, improvement in rural life was based on two aspects: improving access to rural social services; and emphasis on improving the opportunity for individuals to increase their income through their own labor and initiative [38]. Gorbachev also curtailed support for economically weak farms-a hallmark of the Brezhnev era-which in turn facilitated the demise of surrounding villages [39].

The attraction of urban life and enduring deficiencies in rural services and quality of life contributed to the continued contraction in the number of villages. According to the 1989 census, the number of villages decreased from 177,047 in 1979 to 152,922, despite the fact that the policy of village consolidation had ended. Within that trend, the number of villages with 11 to 200 residents fell by nearly $24 \%$, and villages with 200 or more residents declined from 48,076 in 1979 to 42,089 in 1989 . Conversely, the number of villages with fewer than ten residents rose from 23,850 to 30,170 , equal to $20 \%$ of the total number of villages. Villages with fewer than ten residents were considered dying, and non-Black Earth regions had a high percentage of dying villages. In Pskov Oblast, for example, $43 \%$ of all villages were dying, and in neighboring Novgorod Oblast, $37 \%$ of villages were dying [40]. As the Soviet period came to a close, rural depopulation was an ongoing problem and the question of sustainable villages remained acute.

\subsection{The Early Post-Soviet Period}

The steep economic decline during the post-Soviet 1990s exacerbated rural depopulation and the disappearance of villages. Immediately following the dissolution of the Soviet Union, a three-year upsurge in the rural population occurred as Russians living in the Near Abroad returned to Russia. Returnees often chose to settle or were settled in areas classified as rural [41]. Land was allocated to people who wanted to undertake private farming, and temporary housing was constructed for returnee-migrants in order to alleviate pressures on urban housing. After 1994, however, rural depopulation resumed and continued for the next 20 years [42].

Post-Soviet rural depopulation was driven by four trends. First, a widening gap appeared in urban-rural incomes, exacerbated by disproportionately high rural unemployment, fewer job opportunities, and widespread wage arrears. Second, there was a significant decline in rural standards of living, services, and housing in the 1990s. Any progress that had occurred in the 1980s was wiped out. The construction of rural infrastructure was drastically reduced, as seen by the halving of the construction rate of rural dwellings and rural schools. By 1994, the construction of rural roads was one-third compared to its 1991 level [43]. By 1996, the construction of rural kindergartens had declined by a factor of 14 and the number of hospital beds contracted by a factor of five [44]. In addition to deteriorating infrastructure, social services were curtailed as large numbers of rural schools, clubs, and other service and recreational facilities were closed [45]. Inasmuch as rural life was hard in the Soviet era, it became worse in the early post-Soviet period.

Third, demographic trends turned unfavorable as the rural natural increase turned negative. Whereas Soviet rural depopulation was primarily driven by outmigration, starting in 1992 and continuing to 2014, the rural death rate exceeded the birth rate. For more than a decade (1994-2006), 
the number of deaths exceeded the number of births by more than 200,000 annually and averaged 226,000 per annum during this period. An important contributing factor was the collapse of rural healthcare and medical services.

Finally, the uneven economic development that had always plagued the countryside worsened. By late 1990s-early 2000s, the so-called "black holes" became even more pronounced, a term referring to an archipelago of population points between which few people lived, a function of depopulation [46]. Declining soil fertility contributed to lower crop production, a consequence of reduced application of fertilizer and farm de-mechanization. Growing farm debt, low wages, and significant wage arrears exacerbated rural depopulation. Farm employment was not only low-wage but had also become insecure. A minority of households began to adapt incrementally to the new economic environment [47-50]. But the main story in rural Russia during the 1990s was a struggle for survival amidst economic collapse. The effects of these trends were clear. In the 2002 census, the number of villages declined by another 10,000 to 142,200 . Notably, the number of villages with fewer than ten residents rose from 30,170 to more than 34,000 . The problem of sustainable villages continued to worsen.

\section{The Contemporary Problems of Sustainable Villages}

The negative natural increase in the 1990s and net outmigration in the 2000s meant that base of human capital declined significantly in rural Russia, affecting the availability of labor, the quality of farm management and specialists, and the viability of villages [51]. Starting in 2000 and continuing through 2014 there was net migration out of the countryside. Once economic conditions stabilized under President Vladimir Putin, the same motivations that historically pushed people out of the countryside resumed. The number of villages continues to decrease, falling to 133,700 in the 2010 census, concomitant with an increase in the number of villages with few or no residents [52]. From the 2002 to the 2010 census the number of villages with one to ten residents increased from 34,000 to 36,200. By 2010, two-thirds of all villages had fewer than 50 residents. Another 19,400 villages existed only on paper and had no residents. The actual state of rural depopulation may be worse because some villages have many residents who are registered in the village but who live in an urban center, and this is especially common for villages in the non-Black Earth zone of European Russia and in the north. These regions have a high percentage of empty villages. For example, Archangelsk Oblast, located in the far north on the Barents Sea, has one central village with more than 1,000 registered residents. Another four villages have 50-150 residents, 12 villages have 10-49 residents, 25 villages have fewer than ten residents, and 62 villages have no residents but continue to exist in official documents.

The problem of labor shortages and a deficit of highly skilled specialists is acute throughout the agro-industrial complex. The number of workers engaged in agricultural production on large agricultural enterprises declined to two million in 2006 and further fell to 1.8 million in 2008 [53,54]. By 2006, service personnel—persons not involved in agricultural production—comprised only $16.6 \%$ of the 1990 level, and workers employed in the livestock sector were just 19.3\% of the 1990 level. Farm management personnel were at $39 \%$ of the 1990 level and farm specialists were at $42 \%$ of the 1990 level [53,54].

The problem of retaining the rural young is even more severe. A study in Sverdlovsk Oblast showed that the largest group of rural migrants was aged 16-20 [55]. This finding corresponds to the national trend in which the number of rural young aged 19 or less fell from 12 million in 1989 to 9.2 million in 2010 [56]. Rural young (aged 16-30) account for $20 \%$ of the rural population, but comprise nearly one-quarter of the rural poor and extreme poor [57]. The rural young also have a disproportionately high unemployment rate. Faced with these conditions, they leave. By 2013, only $4 \%$ of managers were under 30 years of age, and $14 \%$ were pensioners. For farm specialists, only $6 \%$ were under 30 . And less than $13 \%$ of workers on agricultural enterprises were under 30 , with an ongoing trend of decline [58] (p. 10). The basic problem driving outmigration is that rural life remains less attractive compared to urban life. This problem is exacerbated by access to the Internet, allowing young persons to see the possibility of a better future elsewhere. The days of making material sacrifices 
as the country built socialism are over. People want to be comfortable and they can see how others live. Restrictions on labor movement have been removed, so the main motivators for departure are courage and ambition.

There are myriad reasons for finding rural life unattractive-misguided policies, inadequate funding, neglect, poor governance, other governmental priorities-but at some level, ameliorating rural deficiencies is simply too daunting a mission owing to the vast expanse of rural Russia and the dispersion of rural villages. Improving rural life entails stopping the deterioration of Soviet-era facilities, repairing and updating facilities that still have a usable life span, and constructing new modern facilities to meet contemporary standards. The task is simply enormous and expensive. Russia is a middle-income nation, with a host of other structural socioeconomic problems that need to be addressed as well. Its financial resources are limited, even more so with the decline in the price of oil. And so some rural problems continue to worsen. In the 2008-2013 period alone, the number of rural schools declined by 12,000. During 2000-2013, the number of rural doctors' offices decreased by $65 \%$, and doctors' offices that provide maternity services fell by $22 \%$. Compared to 1990 , the number of cultural facilities in rural areas has fallen by nearly one-quarter [58] (pp. 6-7). Because of rural depopulation and the disappearance of villages, rural dwellers must travel farther for educational, medical, and cultural services. For example, the average distance for a villager to reach a school increased from 12.6 kilometers $(\mathrm{km})$ in 1990 to $15.7 \mathrm{~km}$ in 2014; distance to a hospital increased from $36.9 \mathrm{~km}$ in 1990 to 84.8 in 2014; and distance to a club increased from $11.1 \mathrm{~km}$ in 1990 to $14.4 \mathrm{~km}$ in 2014 [36] (p. 100).

Aside from services, Bondarenko notes that in the contemporary period the countryside is plagued with high unemployment, a poverty rate that is twice as high as in urban areas, and a substantial percentage of housing that lacks basic amenities [36] (pp. 99-100). According to Russian government data, employment in the rural economy (agriculture, hunting, fishing, forestry) decreased to $23 \%$ of rural jobs in 2013, reflecting the shedding of farm labor. The per capita disposable income for rural families was just $61 \%$ that of urban families in 2013. More than $40 \%$ of persons living below the poverty line are found in rural localities [58] (p. 5).

Moreover, remote villages have restricted connections to the outside world that limits income and entrepreneurial opportunity. There are still more than 46,000 villages that are not connected to hard paved roads (equal to $37 \%$ of all villages that have residents), which means that at certain times of the year their roads are all but impassable which limits interaction with external markets and affects the livelihood of residents [59]. Electronic connectivity also lags. In 2013, only 31\% of rural libraries had Internet access, and just one-half of rural families had Internet in their home, compared to $70 \%$ of urban families [58] (pp. 8, 10). Is there any hope?

\section{Factors That Support Sustainability}

The section above depicted a gloomy picture for achieving sustainable villages. This section surveys favorable factors to help achieve sustainable villages. Three strategies are examined.

\subsection{State Assistance Programs}

One strategy to address systemic deficiencies relies on state assistance programs and does not engage the market. The state programs discussed below do not subsidize food production and do not help households accumulate productive capital, and therefore do not contribute directly to increasing income although they may make rural life more livable. When Putin came to office in 2000 he initiated a strategic review of agrarian policy, and in June 2000 the government approved a document that outlined basic directions in agrarian policy from 2001 to 2010. Three strategic tasks of policy were posited in this document. (1) In the economic sphere, the goals were to develop an agro-industrial complex that would allow Russia to integrate with the world economy and compete effectively on the global food market; and to promote national food security, which in the Russian context referred to lowering the level of food imports; (2) In the social sphere, the goals were to improve the quality of 
rural life and to develop rural infrastructure; (3) In the ecological sphere, the goals were to produce safe food products and to protect natural resources through the introduction of ecologically friendly techniques and technology used in food production.

To meet the goals in the social sphere, in December 2002 a state program called "Social Development of the Countryside to 2010" was adopted that took effect in January 2003. It represented the first real attempt to address village sustainability since the Brezhnev period. In 2008, the 2002 program was folded into a broader state program for the development of agriculture and agricultural markets that ran 2008-2012. Subsequently, the original social development program was extended to 2011-2013. During the ten years that the program was in effect, a total of R345 billion was expended, R67 billion of which came from the federal budget. Actual expenditures exceeded the original plan by about R45 billion. The bulk came from investments and loans, about R141 billion, with the remaining R136 billion coming from regional budgets [60]. All federal districts received at least $99.9 \%$ of their planned expenditures, although the distribution of federal money varied by region $[60,61]$. Selected indicators of the 2003-2013 program are illustrated in Table 1.

Table 1. Results during the 2003-2013 Program for Social Development of the Countryside.

\begin{tabular}{|c|c|c|c|c|}
\hline & $\begin{array}{c}\text { Amount Expended, } \\
\text { Rubles * }\end{array}$ & $\begin{array}{l}\text { Quantity of } \\
\text { Construction }\end{array}$ & $\begin{array}{l}\% \text { of Original } \\
\text { Target Fulfilled }\end{array}$ & $\begin{array}{c}\text { Number of } \\
\text { Households Affected }\end{array}$ \\
\hline Housing & 177.5 billion & 18.2 million sq. meters & $138.8 \%$ & 265,700 \\
\hline Gas & 68.6 billion & $62,400 \mathrm{~km}$ of pipes & $154.6 \%$ & 740,000 \\
\hline Running water & 36.8 billion & $18,500 \mathrm{~km}$ local pipes & $46 \%$ & $76,700 * *$ \\
\hline Educational facilities & 25.6 billion & 105,800 places & $53.5 \%$ & - \\
\hline $\begin{array}{l}\text { Health and medical } \\
\text { facilities }\end{array}$ & 8.2 billion & 6,005 hospital beds & $70.3 \%$ & - \\
\hline Sports facilities & 2.5 billion & $\begin{array}{l}304 \text { buildings and } \\
\text { playgrounds repaired }\end{array}$ & $\begin{array}{l}\text { No targets } \\
\text { established }\end{array}$ & - \\
\hline Cultural facilities & 3 billion & 24,590 places & $62.7 \%$ & - \\
\hline $\begin{array}{l}\text { Information-Consulting } \\
\text { centers }\end{array}$ & 198.5 million & $\begin{array}{l}262 \text { information } \\
\text { centers opened }\end{array}$ & $155 \%$ & - \\
\hline $\begin{array}{c}\text { Telecommunication } \\
\text { network }\end{array}$ & 3.9 billion & 706,430 numbers & $71.7 \%$ & - \\
\hline Trade/Services & 6.74 billion & $\begin{array}{l}4,590 \text { retail trade and } \\
\text { social food; } 3,376\end{array}$ & $\begin{array}{l}\text { No targets } \\
\text { established }\end{array}$ & - \\
\hline Roads *** & 44 billion & $\begin{array}{c}9,145.5 \mathrm{~km} \text { of rural } \\
\text { roads }\end{array}$ & NA & - \\
\hline
\end{tabular}

Notes: * Expenditures from all sources: federal and regional budgets, plus off-budget such as loans; ${ }^{* *}$ Number is for 2011-2013 only; *** During 2003-2010 road construction was financed under the social development program and funded with federal, regional, and off-budget money. Starting in 2011 and through to 2013 road construction was made a subprogram of the federal program "Development of the transportation system in Russia" and financed solely by the federal government. Source: Ministry of Agriculture, Itogi realizatsii FTSP 'Sotsial'noe razvitie sela do 2013' za 2003-2013, various pages [60].

The social development program expended the largest amount of money on the construction of subsidized housing for young families and young specialists: R177 billion. During the ten-year program, 265,700 rural families obtained new housing [60] (p. 26). Eligible families received 70\% of the cost of new construction from regional or federal funds. The remainder of the cost could be covered by a family's own money, from various state subsidies, or by obtaining a mortgage in the program that was created in 2006. If a family did not have its own capital to cover the difference, or were not able to secure a mortgage, the program allowed state payments given to mothers for child care to be applied toward the housing. About one-half of participants in the housing project work for farm enterprises and the other half are employed in the social sphere in the countryside [60] (p. 36). In addition, the percentage of rural housing with gas (used mainly for cooking) improved from $34 \%$ in 2003 to almost $57 \%$ by the end of 2013 . The percentage of the rural population with access to running water grew from $41 \%$ in 2003 to 59.6\% in 2013 [62]. Other improvements included a growth in everyday services, up more than three times compared to 2004; more consumer cooperatives that engage in retail 
trade; and more retail markets in rural areas [58] (pp. 8-9). For indices that fell short of original targets, the most commonly cited reason is lack of state funding.

As the 2003-2013 program was nearing expiration, a new federal-funded social development program was adopted in July 2013, called "Stable development of rural territories during 2014-2017 and to 2020" [63]. This program took effect in January 2014. A revised version was adopted by the government in January 2015 that reduced expenditures because of the downturn in the Russian economy [64]. In 2015, R4.07 billion in federal funds were spent on rural housing across 80 regions, helping 7900 families, including 5600 young families and young specialists, receive new housing [65].

Similar to the 2003-2013 program it replaced, the 2014-2020 state program aims to combat rural depopulation by improving the rural standard of living and quality of life. The revised program provides R252 billion (R139 billion from the federal government, R74 billion from regional budgets) to build roads, subsidize rural housing construction, especially for young families, improve the availability for a wide range of services, and improve access to running water and gas in rural housing [66]. Some of the goals articulated in the original (July 2013) version include the following.

- Housing. Build 5.43 million sq. meters of rural housing, including 3.0 million sq. meters for young families and young specialists. Reduce the number of rural families that need improved housing by $16 \%$, and reduce the number of young families and young specialists who need improved housing by $25 \%$.

- Educational facilities. Increase number of seats in general education facilities by 22,300 . Reduce the number of educational facilities that need repair by $7.9 \%$.

- Gas. Bring into operation 18,200 kilometers of gas lines. Increase percentage of rural housing supplied with gas to $61.5 \%$.

- Water. Bring into operation 12,900 kilometers of water pipes. Increase percentage of rural housing supplied with running water to $63 \%$.

- Medical. Bring into operation 858 maternity wards and general practice doctor offices. Increase access to doctor offices for 557,100 persons.

- Cultural facilities. Bring into operation 9900 cultural-recreational enterprises. Increase access to cultural-recreational enterprises for 66,300 persons.

- Sport facilities. Bring into operation 519,200 sq. meters of open air sport areas, increasing access to such facilities for 266,300 persons.

Thus, state financial assistance and investment remains a critically important component in the strategy to combat rural depopulation.

\subsection{Engage the Market with State Assistance}

A second strategy utilizes state assistance but with the intent to engage the market. Specifically, market opportunity arises from support for small farming enterprises. Since 2009, the government has funded a program to create new private farms [67]. In 2014, the farmer program became a subprogram of the state program for the development of agriculture and agricultural markets that runs 2014-2020. By 2020, more than R13.8 billion will be expended, of which R8.3 billion will come from the federal budget. The goals are to create an additional 14,000 private farms and more than 42,000 new jobs. In addition, the program aims to create or modernize 1300 family dairy farms. The program also includes subsidies to help private farmers convert nearly one million hectares of agricultural land into private property.

A person who desires to begin private farming is eligible to apply for a one-time grant to obtain construction materials for housing, an automobile, furniture, and equipment such as a computer, phone, and to supply the dwelling with gas, hot water, electricity, and Internet connection. The grant, which is reviewed and distributed locally, cannot exceed $90 \%$ of the cost of start-up materials. That same person may apply for a grant from the program to develop family dairy farms. The grant may be used to 
obtain construction materials to repair or build farm facilities, including processing, and to obtain livestock. The grant may not exceed $60 \%$ of planned expenditures.

These two initiatives are geared toward increasing food production on commercialized enterprises that also pay taxes on their earnings. The steps are important because the value of private farming production has been growing more rapidly than from the large farm or household sectors in recent years. Moreover, successful private farmers have the highest income among rural households, and therefore serve as an example as to what entrepreneurship can achieve.

\subsection{Engage the Market with Individual Enterprise}

A final strategy for policy action is based on utilizing market opportunity. This range of opportunity is broadly defined as increasing production capital, raising household income, and improving the welfare of rural families to address village sustainability. Market opportunity shifts responsibility for action from the state to the individual. This opportunity builds on the change in mindset since market reform was introduced. The change is measurable attitudinally. Efendiev and Sorokin note that, "individualism and entrepreneurial activity are growing rapidly in the past 13 years" [68]. The change in mindset is also measurable behaviorally, at least among a subset of rural households. The same authors observed that villagers "showed strong preference for working on their own land and making profit of it" [68].

Market opportunity leads to the diversification of household income by pursuing mixed income stratagems. Various studies have quantified how reliance on transfer payments and farm wages have decreased, while entrepreneurial activity has increased through household enterprise $[49,50,69,70]$. Further, the characteristics of rural households that have higher income, that are more commercialized, and that have greater wealth have been analyzed. Households with a greater labor value have higher income, thus contributing to village inequality, but are also positioned as demographic anchors in the community [71]. What is important here is the quality of labor, the labor potential of household members, and not just the number of household members [47] (pp. 79-93). The problem is that relatively few households have sufficient labor capital. These demographically advantaged households are able to distinguish themselves economically, but they are a distinct minority.

Although engaging the market has the potential to create incentives not to migrate, at the same time it should be clearly noted that engagement with the market is not unambiguously positive. In an economic environment in which price disparities exist between agriculture commodities and industrial inputs, engagement with the market may be detrimental. Production and exchange relationships have to calculated carefully or the household could end up worse off financially. The price disparity in rural Russia provides an example. Using an index of wholesale prices, whereby $1999=100$, by 2010 , agricultural prices had increased $434 \%$ though prices for industrial inputs grew 553\%. From 2010 through 2014, agricultural prices rose another 137\%, and industrial prices increased by $232 \%$ [48]. For the entire 1999-2014 period, agricultural wholesale prices rose $570.5 \%$ against a $784.6 \%$ increase for industrial prices [72]. Fortunately for most households, they do not use mechanized production processes and therefore are sheltered from price disparities. In this sense, household dependence on manual labor is a positive.

Moreover, there are other factors that may hinder market engagement by households. One set of factors concern spatial dispersion of urban centers and insufficient rural infrastructure that make access to markets problematic. Another set of factors has to do with market information. It is difficult to price goods and services accurately without market information, but village life often lacks access to hard information for all except a small minority of households. There are also problems with corruption and protection of property rights. A household in a village with good location may come under legal or illegal pressure by outsiders to sell its property. Finally, a household's economic status in the village and the possibility of social exclusion influence expected economic benefits of market engagement. The point is that market engagement is not as simple or straightforward as it may appear, and desire to engage the market is separate from an ability to engage successfully. 


\section{Assessment}

The depopulation of rural Russia and contraction in the number of villages has occurred for three main reasons. First, during the first half of the twentieth century rural depopulation was linked to urbanization and industrialization. This was a long-term historical process that occurred in other nations and was not unique to Russia. A second reason for rural depopulation is structural, referring to village location and proximity to an urban center. In the Soviet period, remoteness was a motivation to leave, whereas in the post-Soviet period one finds the simultaneous decay of remote villages from outmigration combined with pressure from urban encroachment as suburbs spread outward. In addition, rural land has transformed into peri-urban land as weekend dachas for urbanites are constructed on land from bankrupt farm enterprises. In other words, villages are under assault from without and from within. As a consequence, rural Russia experiences land abandonment in peripheral areas and land shortages surrounding cities.

In addition, structural changes in the food production system in the contemporary period have consequences on rural employment. The number of private farms, micro-farms, and medium-sized farms has increased as a result of farm privatization, but these types of farms utilize less hired labor. The debt of large farms in 2013 reached R119.6 million per enterprise ( $\$ 2.3$ million per farm at 2013 exchange rates), which meant that the majority lacked the financial means to expand hiring or replace manual labor with mechanization [73]. Some, but a relatively small number of large farming enterprises, have adopted mechanized processes to compensate for labor shortages, primarily on dairy farms.

The third reason for depopulation is behavioral, exacerbated "by a striking differential in the quality of rural versus urban life, far greater than in any economically advanced country" [46] (p. 87). Urban bias existed during the Stalin period. Some attempts were made after Stalin to moderate this policy. However, the countryside still lags in its standard of living and amenities. A report released by the Federation Council in early 2014 clearly articulated that a significant gap continues to exist between rural and urban life in many dimensions [57] (pp. 16-64). Moreover, pressure on the federal budget due to the recent slowing in the Russian economy has reduced spending plans going forward. In particular, regional governments are having a hard time meeting their financial obligations to the 2014-2020 rural development program. During 2015, for example, regional financing for rural areas decreased by one-half [74]. Social development goals already have a lower priority than food production and receive less funding. In 2016, only 7000 out of 153,000 villages are due to receive subsidies for housing for young families [75]. These deficiencies continue to drive motivations to leave the countryside.

What, then, are the prospects for sustainable villages in Russia? The picture is decidedly mixed. As noted above, the task of creating sustainable villages is enormous and the challenges are both deep and wide. Depopulation continued despite the fact that the 2003-2013 program led to improvement in some aspects of rural life, exceeding 769,900 persons from outmigration during 2009-2013 [36] (p. 100). The final two years of the program actually witnessed a net increase in rural outmigration: 166,600 persons in 2012 and 176,800 persons in 2013 [58] (p. 4). Rural depopulation and the disappearance of villages will continue in reaction to the conditions and quality of rural life. Moreover, Russia on a comparative basis continues to have a large percentage of its population employed in agriculture and living in rural areas. A further contraction in the rural population and number of villages is therefore likely as Russia gravitates toward normalcy for a developed state. Russia's state statistical agency, Rosstat, estimates that the rural population will contract from 36.9 million in 2014 to 32.0 million by the beginning of 2023 [75].

That said, one can imagine a base of sustainable villages emerging. These villages are likely to have specific characteristics. First, they are likely to have a good location and be connected to the outside world by a road system. "Good location" means different things in different areas of Russia. Good location can refer to being in the south where agricultural production is profitable and climatic conditions are less harsh. In the non-Black Earth zone and north, good location means having 
proximity to an urban center. Especially in the north, village location has an enormous impact on the ability to engage in household enterprise and household income [71] (pp. 170-195).

A second characteristic is that village households are likely to be engaged in non-farm employment and economic activity other than food production. The basic question each household (and individual) faces is how to best survive, or prosper, in a market environment. For some, it makes sense to leave the countryside. For others, staying in the countryside but pursuing a mixed income strategy makes sense. Income diversification is sensible because first, most rural households have labor deficiencies; second, income from farming and agriculture is significantly below non-agricultural employment; and third, new opportunities are available and attractive. For example, in late 2015 the State Duma began discussion to change Article 19 in the Law on Private Farming [76]. The change would allow private farmers to offer rural tourism services, thereby augmenting income possibilities during the non-growing season, or offering income diversification for private farmers who are located in poor agricultural regions. Although Russia has a program for the development of domestic tourism that runs 2011-2018, there is no formal program for the development of rural tourism. Rural tourism accounted for only about $2 \%$ of all domestic tourists within Russia in 2013 [77] (pp. 75-76). There is thus clear potential for growth in this market, especially since demand for rural tourism is growing in areas of heavy urbanization. In addition, more Russians are traveling domestically due to the decline of the ruble and travel bans to Ukraine, Egypt and Turkey, which had been popular foreign destinations.

The potential of rural tourism remains largely untapped. But there is a lot of work to do. Regulatory oversight and established standards are lacking. There is no coordination among state and private sectors in rural tourism. In fact, there is not even agreement about what rural tourism is and it is referred to in varying ways: green tourism, farmer tourism, eco-tourism, agro-tourism, village tourism, among others. The entire genre has an ad hoc quality, encompassing a number of different activities: homestays in villages, excursions to food production and processing enterprises, and cultural-ethnographic excursions and events. As tourism standards are established and regulatory oversight improves, thereby providing the tourist with more transparency about what can be expected, this business-service segment may see robust growth that could help villages survive.

A third characteristic of sustainable villages is that their demographic composition will be a mix of urban and rural residents. The traditional pattern has been for villagers to move to a city, leaving a core of rural folk. In the future, one can imagine the emergence of sustainable villages on the basis of peri-urban villages with good proximity that become integrated as urbanites move there permanently, seasonally, or on weekends. A "back to nature movement" by urbanites is not at all hard to imagine given desires to decompress from stressful urban life. Already, something similar happens every weekend as urbanities commute to their dachas for rest and relaxation. Rural communities populated by urban residents, called rodorye pomest'ia, are increasingly popular outside of large cities. In 2014, the author visited a planned rural community located about 40 minutes outside the city of Vladimir. These permanent communities offer a rural lifestyle with some land to raise a few chickens or small animals along with urban-type amenities: solar power for electricity, running water, indoor plumbing, and good quality housing. In principle, an influx of urbanites into villages will create demand for more and better services, and provide opportunity for non-agricultural employment for villagers.

\section{Conclusions}

A good part of Russia's sustainable village problem may be attributable to unique factors: Stalinist urban bias, the Soviet economic model and its non-market approach to rural development, the extreme poverty of rural life, the expanse of Russia's "ruralness," the dispersion of villages, and the spatial concentration of services. Historically, sustainable villages have been crucial to food production and for supplying labor to farms. That model is changing somewhat as migratory labor in agriculture has increased, as mechanization replaces manual labor, and as rural incomes diversify away from dependence on farm employment. Even so, sustainable villages remain important to the vibrancy of the countryside both culturally and economically. 
In the West, it is popular to equate sustainable agriculture with sustainable rural communities. In particular, the food sovereignty movement is considered as an alternative model to industrial agriculture. Food sovereignty represents a new green revolution that revolves around agroecology. Food sovereignty, as defined by the peasant federation La Via Campesina, is "the right of people to healthy and culturally appropriate food, produced through ecologically sound and sustainable methods, and their right to define their own food and agricultural systems [78] (p. 95)." Agroecology stands in contrast to industrial agriculture. Agroecology is knowledge intensive, as opposed to capital intensive; it tends toward small highly diversified farms as opposed to large, non-diversified farms; and it rests on the ability of local communities to innovate through farmer-to-farmer research as opposed to technology and information coming from above through government and private industry agents [78] (p. 92). Thus, agroecology is a barrier to the expansion of industrial agriculture. Is food sovereignty applicable as a model for sustainable villages in contemporary Russia?

Although rural household production is already "green"—using organic fertilizer, and eschewing antibiotics and growth hormones-food production is based largely on manual labor. At best, food sovereignty and agroecology are only partially relevant to rural Russia, at least as defined in the literature where food sovereignty appears as a form of post-materialism and founded on a high level of consciousness about the politics of food production. McMichael describes food sovereignty as a vision that disrupts the state-centric mold, that calls for the right to self-governance, and that embeds social relations in ecology rather than markets [15] (p. 59). Those three conditions hardly seem relevant in Putin's Russia based on a strong state, a strong center, and the hold of large agrofirms on agricultural markets.

Moreover, the market infrastructure that food sovereignty assumes often is weakly developed in Russian villages. One of the notable features of post-Soviet life is the sale of household production to intermediaries. Pallot and Nefedova describe how refrigerated trucks arrive in villages to buy vegetables, meat, and live animals from households, who prefer to take lower prices than bear the cost of transportation to urban markets [79] (p. 191). In other cases, market infrastructure is nearly absent. Villages without hard-paved roads are cut off from outside markets for several weeks a year. Households that wish to market their production are restricted to local markets, selling to other households that grow similar commodities and have limited incomes. Russian leaders who want to emphasize the contribution of the private sector cite government statistics to show that over $50 \%$ of the ruble value of food production comes from household production and private farms [80] (p. 275). But the value of production is not the same as the volume or value of food sales. Household food production is legally "non-commercial" and income from food sales is not subject to taxation so it is hard to compute actual volume of sales because the Russian government does not collect these data $[80,81]$. Household production remains a niche producer for potatoes, vegetables, and eggs. Households also engage in meat and milk production but since these are perishables, relatively little is sold. This sector is not able to fulfill the broad spectrum of fresh and processed food desired by the urban population. Only the most idealistic would argue that a food system based on food sovereignty can feed Russia.

What does it mean? Russia remains wedded to an industrial model of agriculture, which means that production processes are capital intensive and require a range of industrialized inputs. There is no national food sovereignty program, and leaders do not talk about food sovereignty when discussing how to attain self-sufficiency or develop rural areas. An alternative model such as food sovereignty is unable to feed the country and does not appear to be a viable model for rural development. Because Russian agriculture remains based on a model of industrialism, large farms need labor and sustainable villages. To the extent that social policy is unable to bridge the gap labor shortages persist. There is little to suggest that the problem of sustainable villages will suddenly disappear. The upshot is that Russia's quest for sustainable villages will remain a struggle. 
Acknowledgments: This research was supported by the Norwegian Research Council, grant number 243630/H30.

Conflicts of Interest: The author declare no conflict of interest.

\section{References and Notes}

1. Sachs, J.D. The Age of Sustainable Development; Columbia University Press: New York, NY, USA, 2015; pp. 5, 393-445.

2. United Nations Commission on Sustainable Development. Framing Sustainable Development: The Brundtland Report-20 Years On. 2007. Available online: http://www.un.org/esa/sustdev/csd/csd15/ media/backgrounder_brundtland.pdf (accessed on 12 February 2016).

3. Collier, P. The Bottom Billion. Why the Poorest Countries are Failing and What Can be Done About It; Oxford University Press: Oxford, UK, 2008.

4. Food and Agriculture Organization of the United Nations. The State of Food Insecurity in the World; FAO: Rome, Italy, 2015.

5. Lengnick, L. Resilient Agriculture: Cultivating Food Systems for a Changing Climate; New Society Publishers: Gabriola Island, BC, Canada, 2015; p. 24.

6. Brown, L.R. Full Planet, Empty Plates: The New Geopolitics of Food Scarcity; W.W. Norton and Co.: New York, NY, USA, 2012; pp. 10-11.

7. Lipton, M. Why Poor People Stay Poor: Urban Bias in World Development; Harvard University Press: Cambridge, MA, USA, 1976.

8. Bates, R.H. Markets and States in Tropical Africa: The Political Basis of Agricultural Policies; University of California Press: Berkeley, CA, USA, 1981.

9. Bates, R.H. Essays on the Political Economy of Rural Africa; University of California Press: Berkeley, CA, USA, 1983.

10. Sadowski, Y. Political Vegetables?; The Brookings Institution: Washington, DC, USA, 1991.

11. Special Issue Beyond Urban Bias, Journal of Development Studies 29, 1993.

12. Thiesenhusen, W.C. Broken Promises: Agrarian Reform and the Latin American Campesino; Westview Press: Boulder, CO, USA, 1995.

13. For a contrary view to urban bias see Byres, T.J. Of Neo-Populist Pipe-Dreams: Daedalus in the Third World and the Myth of Urban Bias. J. Peasant Stud. 1979, 6, 210-244.

14. Kliff, T. Gosudarstvennyi kapitalizm in Rossii (State Capitalism in Russia); Legiia: Moscow, Russia, 1991.

15. McMichael, P. Food Regimes and Agrarian Questions; Fernwood Publishing: Halifax, NS, Canada, 2013; pp. 21-40, 57-60. (In Russian)

16. Goskomstat. Naselenie Rossii za 100 let (1897-1997) (Population of Russia for 100 years (1897-1997)); Goskomstat: Moscow, Russia, 1998; p. 32. (In Russian)

17. Smith, J.A. Works in Progress: Plans and Realities on Soviet Farms, 1930-1936; Yale University Press: New Haven, CT, USA, 2014; pp. 54-55.

18. Medvedev, R.A.; Medvedev, Z.A. Khrushchev: The Years in Power; W.W. Norton and Co.: New York, NY, USA, 1978.

19. Smith, G.A.E. Agriculture. In Khrushchev and Khrushchevism; McCauley, M., Ed.; Indiana University Press: Bloomington, IN, USA, 1987; pp. 95-117.

20. Pallot, J. Rural Depopulation and the Restoration of the Russian Village under Gorbachev. Sov. Stud. 1990, 42, 658-659. [CrossRef]

21. Over time the number of viable and non-viable villages was revised.

22. Ioffe, G.; Nefedova, T. Continuity and Change in Rural Russia: A Geographical Perspective; Westview Press: Boulder, CO, USA, 1997; p. 128.

23. The number of villages declined from 294,059 in 1959 to 177,047 in 1979.

24. Wadekin, K.E. The Nonagricultural Rural Sector. In The Soviet Rural Community; Millar, J.R., Ed.; University of Illinois Press: Urbana, IL, USA, 1971; pp. 163, 169-170.

25. Darchiev, I.D. Sblizhenie uroveniia zhizni gorodskogo i sel'skogo naseleniia (Bringing together standards of living of the urban and rural populations). Znanie 1981, 10, 3-62.

26. Pavlovskaia, E.; Pisareva, L. Material'ne i kulturno-bytovye usloviia zhizni kolkhoznikov (Material and cultural-service conditions of collective farmer workers). APK Ekon. Upr. 1989, 3, 78-82. 
27. Goskomstat. Lichnoe podsobnoe khoziaistvo naseleniia $v 1988$ godu (Subsidiary farming by the population in 1988); Goskomstat: Moscow, Russia, 1989; p. 9. (In Russian)

28. Naukhatskiy, V.V. Modernizatsiia sel'skogo khoziaistva i Rossiiskaia derevnia 1965-2000 (The modernization of agriculture and the Russian countryside 1965-2000); Ministry of Education of the Russian Federation: Rostov, Russia, 2003; pp. 89, 100-101, 104-105. (In Russian).

29. Evans, A. Equalization of Urban and Rural Living Levels in Soviet Society. Sov. Union 1981, 8, 38-61. [CrossRef]

30. Rural dwellers were not alone in being under-serviced. In the 1970s, interfarm associations were formed to provide services to collective farms, which otherwise "lacked both the manpower and resources necessary to sufficiently service [their] own infrastructure". Interfarm associations were formed using shared labor. Specialists were freed from farm labor and assigned to small-scale construction projects. Later, interfarm associations were set up for livestock farming and food processing. See Litvin, V. The Soviet Agro-Industrial Complex: Structure and Performance; Westview Press: Boulder, CO, USA, 1987; pp. 9-10.

31. Postanovlenie Tsentral'nogo komiteta KPSS i Soveta Ministrov SSSR. O merakh po dal'neyshemu razvitiiu sel'skogo khoziaistva nechernozemnoi zony RSFSR (On Measures for the Further Development of Agriculture in the Non-Black Earth Zone of the RSFSR). Resheniia partii i pravitel'stva po sel'skomu khoziaistvu (1965-1974 gg.); Kolos: Moscow, Russia, 1975; pp. 889-904. (In Russian)

32. Schroeder, G. Rural Living Standards in the Soviet Union. In The Soviet Rural Economy; Stuart, R.C., Ed.; Rowman and Allanheld: Totowa, NJ, USA, 1983; pp. 241-257.

33. Tsentral'noe statisticheskoe upravlenie RSFSR. Narodnoe khoziaistvo RSFSR v 1982 g; (National Economy of the RSFSR in 1982); Finansy i statistika: Moscow, Russia, 1983; p. 5. (In Russian)

34. During this time period the rural natural increase was positive and the death rate was relatively low, so population decline was due to outmigration.

35. Pravda, 13 April 1989; 2.

36. Bondarenko, L. Preodolenie razlichii mezhdu gorodom i derevnei: istoriia i sovremennost' (Overcoming differences between city and countryside: history and contemporary). APK: Ekon. Upr. 2015, 10, 98-100. The 1990 law was rescinded in 2004. (In Russian)

37. Cook, L.J. Brezhnev's 'Social Contract' and Gorbachev's Reforms. Sov. Stud. 1992, 44, 37-56. [CrossRef]

38. Sidorova, M. Sblizhenie uroveniia i uslovii zhizni gorodskogo i sel'skogo naseleniia (Bringing together the level and standards of living of the urban and rural population). Ekon. Sel'skhogo Khoziaistva 1987, 11, 52-54. (In Russian)

39. Wegren, S.K. Agriculture and the State in Soviet and Post-Soviet Russia; University of Pittsburgh Press: Pittsburgh, PA, USA, 1998; pp. 51-57.

40. Nefedova, T. Sel'skaia Rossiia na pereput'e (Rural Russia on the precipice); Novoe: Moscow, Russia, 2003; p. 332. (In Russian)

41. The Federal Migration Service had an interest to settle newcomers in rural areas because urban unemployment was spiking and there were housing shortages. Newcomers had an interest to settle in rural areas in order to gain access to land to grow food for subsistence.

42. A net reduction in the size of the rural population occurred in every year from 1995 through 2014 with the exception of 2004. In 2004, administrative reclassification of urban settlements to rural led to an increase in the size of the rural population on paper. Without these changes the rural population would have declined.

43. Terent'ev, I. Itogi raboty agropromyshelnnogo komleksa v 1994 g. (Results of Labor in the Agroindustrial Complex in 1994). Ekonomist 1995, 4, 51-65. (In Russian)

44. Petrikov, A.V. Sotsial'nye problemy Rossiiskoi derevni (Social problems of the Russian countryside) in Ekonomicheskie i sotsial'nye problemy agrarnogo sektora (Economic and social problems of the agrarian sector). Petrikov, A.V., Ed.; Russian Academy of Sciences: Moscow, Russia, 1998; p. 164. (In Russian)

45. Evans, A.B., Jr. The Decline of Rural Living Standards in Russia in the 1990s. J. Commun. Stud. Transit. Polit. 1996, 12, 293-314. [CrossRef]

46. Ioffe, G.; Nefedova, T.; Zaslavsky, I. The End of Peasantry? The Disintegration of Rural Russia; University of Pittsburgh Press: Pittsburgh, PA, USA, 2006; pp. 87, 145-154.

47. O’Brien, D.J.; Patsiorkovsky, V.V.; Dershem, L.D. Household Capital and the Agrarian Problem in Russia; Ashgate: Aldershot, UK, 2000; pp. 79-93, 131-190. 
48. Kalugina, Z.I. Survival Strategies of Enterprises and Families in the Contemporary Russian Countryside. In Russian Views of the Transition in the Rural Sector: Structure, Policy Outcomes, and Adaptive Responses; Norsworthy, L.A., Ed.; The World Bank: Washington, DC, USA, 2000; pp. 118-131.

49. Wegren, S.K. The Moral Economy Reconsidered: Russia's Search for Agrarian Capitalism; Macmillan: New York, NY, USA, 2005; pp. 105-152.

50. O'Brien, D.J.; Wegren, S.K.; Patsiorkovsky, V.V. Contemporary Rural Responses to Reform from Above. Russian Rev. 2004, 63, 256-276. [CrossRef]

51. Bautin, V. Sovremennaia ekonomika i chelovecheskii capital v APK (The contemporary economy and human capital in the APK). APK Ekon. Upr. 2011, 8, 19-24. (In Russian)

52. During 2002-2010, the number of villages with 11-50 residents declined by 5400; villages with 51-100 residents declined by 1,100; villages with 101 to 500 residents declined by 2900; villages with 501 to 1000 residents declined by 1,100; and villages with 1000-3000 residents declined by 400. Rosstat, All-Russian Census of 2010; (in Russian). Rosstat: Moscow, Russia, 2010.

53. Ushachev, I. Proizvoditel'nost' i motivatsiia truda—vazhneishie factory ekonomicheskogo razvitiia sel'skogo khoziaistva (Productivity and motivations of labor-important factors for the economic development of agriculture). APK Ekon. Upr. 2008, 1, 4. (In Russian)

54. Bogdanovskii, V. Problemy zaniatosti v sel'skokhoziaistvennykh organizatsiiakh (Problems of employment in agricultural enterprises). APK Ekon. Upr. 2010, 1, 27. (In Russian)

55. Filippov, N.N. Degradatsiia chelovecheskogo i kadrovo potentsiala na sele (The degradation of human and cadre potential in the countryside). Ekon. Sel'skokhoziaistvennykh Pererabat. Predpr. 2007, 7, 13. (In Russian)

56. Rosstat. Demograficheskii Ezhegodnik Rossii 2010; Rosstat: Moscow, Russia, 2010; pp. 44-45. (In Russian)

57. Rural areas have a lower percentage of the population that is employed; they have higher unemployment (which is under-reported anyway); there is a persistent gap between average income levels and disposable income between urban and rural households, and this gap is growing; the rural diet is less varied and consists of more starches and carbohydrates; and access to a range of rural services and facilities continues to lag. Federation Council of the Russian Federation. Doklad ob ustoichivom razvitii sel'skikh territorii Rossiiskoi Federatsii (Report on the Stable Development of Rural Areas of the Russian Federation); The Kremlin: Moscow, Russia, 2014; pp. 16-64. (In Russian)

58. Government of the Russian Federation. Strategiia ustoichivogo razvitiia sel'skikh territorii Rossiiskoi Federatsii na period do 2030 goda (Strategy for stable development of rural territories of the Russian Federation to 2030); pp. 4-8, 10. 2 February 2015. Available online: www.government.ru (accessed on 10 February 2015). (In Russian).

59. Ministry of Agriculture. Finansirovanie APK sleduet ostavit' kak minimum na urovne 2015 goda (The financing of the agroindustrial complex must remain on the level of 2015 as a minimum). 8 February 2016. Available online: www.mcx.ru (accessed on 8 February 2016). (In Russian).

60. Ministry of Agriculture. Itogi realizatsii FTSP 'Sotsial'noe razvitie sela do 2013' za 2003-2013 (Results of Implementing the Federal Special Purpose Program 'Social Development of the countryside to 2013' During 2003-2013); Ministry of Agriculture: Moscow, Russia, 2014; pp. 16, 18-19, 26, 36. (In Russian).

61. From federal funds the Volga federal district received the highest amount at R18.8 billion, and the Central region was second at R13.6 billion. At the low end were the Northwest district and the Far East district, which received R2.9 billion and R3.1 billion respectively.

62. Access to running water is defined as water piped directly to a household, or access to a communal pump located in a village or rural population point.

63. The program is to be implemented in two phases, 2014-2017, and 2018-2020.

64. The revised version of the program, issued in January 2015, decreased total expenditures from R299 billion in the original program to R252 billion.

65. According to the Ministry of Agriculture, 549,100 square meters of new housing were constructed, of which 378,000 square meters were received by young families and specialists. IA Regnum. Luchshe vsego uluchshaiut zhilishchnye uslovaiia selian v 8 sub'ektakh RF (Best of all the living conditions of villagers in 8 regions of Russia is improving). 19 January 2016. Available online: www.mcx.ru (accessed on 19 January 2016). (In Russian). 
66. Government of the Russian Federation. Postanovlenie ot 16 Yanvaria 2015 g. no. 17 (Resolution from 16 January 2015 no. 17). 16 January 2015. Available online: www.mcx.ru (accessed on 16 January 2015). A subsequent "Strategy for stable development of rural territories to 2030" was adopted in February 2015, defining broad goals and objectives for the program to achieve. (In Russian)

67. During 2009-2014 the program was called "Beginning private farmer." From 2014 to 2020 the beginning farmer program is subsumed under the subprogram called "Support for small forms of farming."

68. Efedniev, A.; Sorokin, P. Rural Social Organization and Farmer Cooperatives Development in Russia and other Emerging Economics: Comparative Analysis. Dev. Country Stud. 2013, 3, 111.

69. O'Brien, D.J.; Patsiorkovsky, V.V. Measuring Social and Economic Change in Rural Russia: Surveys from 1991 to 2003; Lexington Books: Lanham, MD, USA, 2006; pp. 75-110.

70. O'Brien, D.J.; Wegren, S.K.; Patsiorkovsky, V.V. Structure of Income, Mental Health, and Quality of Life in Rural Russia. Eur.-Asia Stud. 2010, 63, 597-614. [CrossRef]

71. Wegren, S.K. Rural Inequality in Divided Russia; Routledge: London, UK, 2014; pp. 97-123, 170-195.

72. Epshtein, D. Gospodderzhka sela: deklaratsii i fakty (State Support for the Countryside: Statements and Facts). Available online: http:/ / k-vedomosti.ru (accessed on 3 November 2015). (In Russian).

73. Adukov, R.K.; Adukova, A.N.; Iusufov, R.A. Upravlenie sel'skim razvitiem: neobkhodimost' i puti usileniia vnimaniia k chelovecheskomu factory (Managing Rural Development: Necessity and Paths of Strengthening Attention to the Human Factor). Ekon. Sel'skokhoziaistvennykh Pererabat. Predpr. 2015, 7, 48.

74. Anisimov, S. Molodym sem'iam men'she podderzhki (Young families get less support). Sel'skaia zhizn', 17-23 December 2015, 1. (In Russian).

75. The population decline appears to be accelerating. From 1989 to 2002 Russia lost 10,000 villages and a net of 200,000 rural dwellers. From 2002 to 2010 another 8500 villages disappeared but the rural population contracted by one million.

76. Sel'skii turizm-v zakone (Rural Tourism-in the law). Sel'skaia zhizn', 22-28 October 2015, 2. (In Russian).

77. Novikov, V.; Zhubarkin, S. Agrarnyi turizm kak factor territorial'nogo razvitiia i diversifikatsii sel'skoi ekonomiki (Agrarian tourism as a factor in the territorial development and diversification of the rural economy). APK Ekon. Upr. 2013, 10, 75-76. (In Russian)

78. Holt-Gimeniz, E.; Altieri, M.A. Agroecology, Food Sovereignty, and the New Green Revolution. Agroecol. Sustain. Food Syst. 2013, 37, 92, 95.

79. Pallot, J.; Nefedova, T. Russia's Unknown Agriculture: Household Production in Post-Socialist Rural Russia; Oxford University Press: Oxford, UK, 2007; pp. 191, 195-197.

80. In $2014,10 \%$ of the ruble value of food production came from private farms and $41 \%$ from household plots. Private farm data include individual entrepreneurs. Rosstat. Rossiia $v$ tsifrakh (Russia in Figures); Rosstat: Moscow, Russia, 2015; p. 275. (In Russian)

81. O limite na skotinu $\mathrm{v}$ podsobnykh khoziaistvakh (About limits on cattle in subsidiary farming). Sel'skaia zhizn', 27 August-2 September. 2015; 2. (In Russian).

(C) 2016 by the author; licensee MDPI, Basel, Switzerland. This article is an open access article distributed under the terms and conditions of the Creative Commons Attribution (CC-BY) license (http://creativecommons.org/licenses/by/4.0/). 